\title{
ENSAIO CRÍTICO SOBRE A PRIMEIRA E A SEGUNDA ANTINOMIAS DE KANT
}

\author{
A rmando Lopes de Oliveira \\ UFMG
}

Resumo: Neste trabalho mostro como as duas primeiras antinomias cosmológicas de Kant, a do espaço-tempo e a da simplicidade-complexidade, sofrem uma verdadeira reviravolta com a cosmologia atual (Big Bang), a física de partículas (teorias da relatividade e quântica) e as formulações recentes de fractais-caoscomplexidade.

Palavras-chave: Kant, Antinomias, Cosmologia, Física Recente.

Abstract: In this paper I show how the space-time and the simplicity-complexity, the first two Kant's cosmological antinomies, undergo a true overturn as a consequence of the new cosmology (Big Bang), particle physics (relativity and quantum theories) and the last results of fractals-chaos-complexity.

Key words: Kant, Antinomies, Cosmology, New Physics. 


\section{Introdução}

ant (1724-1804) afirma repetidas vezes, dando a isso sempre muita ênfase, que a ruptura com os paradigmas passados, desencadeada pela sua proposta filosófica, estaria fadada a provocar uma nova revolução copernicana. A primeira ocorreu no domínio da física e da astronomia por obra e graça de Galileu (15641642), Kepler (1571-1630) e Newton (1642-1727): a Terra foi arrancada de sua imobilidade, no centro do Universo, e colocada girando em torno do Sol. É como se perdêssemos o pé na realidade, findo o privilégio de nos situarmos como observadores imóveis e privilegiados, situados no centro de toda realidade sensível.

A fonte da episteme, no que diz respeito às grandes correntes filosóficas clássicas, desde a passagem do mito ao logos, ocorrida na Grécia Antiga por volta do século VII a. C., esteve sempre centrada fora do homem: no cosmo, para empiristas e aristotélicos; no mundo das idéias, para racionalistas e platônicos. A segunda revolução copernicana, que Kant meticulosamente inaugurou, diga-se de passagem, teve em Descartes (15961650), o fundador da filosofia moderna, um de seus precursores, e da mais alta importância. Se não tivesse havido o apelo ao cogito ergo sum (penso logo existo) cartesiano, como primeira e inabalável evidência, mal conseguiríamos imaginar a possibilidade da proposição das três Críticas de Kant: a da Razão Pura, a da Razão Prática e a do Juízo.

Filosofia clássica, centrada ou na realidade sensível ou no mundo das idéias como alternativas únicas para epistemes verdadeiras, marcou um filosofar para o qual cabe a metáfora de pré-copernicano. 0 kantismo, centrado pura e exclusivamente no próprio homem como fulcro de toda e qualquer episteme válida, coloca-se como uma verdadeira segunda revolução copernicana, inteiramente antípoda da primeira, tendo ocorrido a partir de Kant, no domínio da filosofia, e não mais no campo da física e da astronomia como aconteceu na primeira.

No meu entender, estamos no limiar de uma terceira revolução copernicana, em movimento pendular, sempre com surpresas, mudanças de paradigmas, rupturas epistemológicas. Contrapondo-se ao antropocentrismo à moda kantiana, modo de pensar que nasceu com a marca do novo e do inusitado, mas que apresenta hoje sinais de exaustão, vislumbra-se um novo cosmocentrismo, de repercussões insuspeitáveis e apenas começadas. Pensar Kant sem ter havido GalileuKepler-Newton parece impossível. Apenas uma amostragem: a Crítica da Razão Pura é em grande parte uma resposta filosófica ao prestígio da nova ciência criada por aqueles três gênios. Como não encará-la como uma tentativa de justificativa lógica das condições subjetivas a priori da possibilidade de se edificar uma ciência física do tipo da philosophia naturalis de Newton? Isto é tão verdade, que Kant chega a propô-la 
como paradigma inigualável de ciência verdadeira: nada cega, porque expressa em linguagem matemática (detentora de formas ou conceitos verdadeiros); em nada vazia, porque carregando em seu bojo intuições espaço-temporais (matéria ou substrato necessário a todo conhecimento da realidade sensível). Na sua formulação lapidar: todo conceito sem intuição é vazio, toda intuição sem conceito é cega.

\section{Vertigens no ínfimo e no imenso}

Como veremos logo abaixo, a primeira antinomia cosmológica proposta por Kant é a da finitude-infinitude do espaço e do tempo. Prelibando o que será esse nosso ensaio crítico, antecipo que a ciência física leva-nos hoje a uma transposição daquela antinomia de Kant para um cenário de complementariedade entre o ínfimo e o imenso, tendo-se varrido para fora 0 infinito.

Visualizações dentro do cenário do ínfimo e do imenso, para o qual nos empurra a física atual, não são de forma alguma destituídas de interesse. Acordei hoje com a obsessão das escalas. Ao escovar meus dentes perguntei a mim mesmo: em que escala estou em relação à minha escova de dentes? Fiz uma avaliação rápida: existe uma razão aproximada de $18 \mathrm{~cm}$ para $1,80 \mathrm{~m}$, ou seja, se minha escova de dentes fosse um lilliput em carne e osso, eu seria sentido por ela como uma pessoa 10 vezes mais alta. Sensação certamente não muito confortável para 0 lilliput! No entanto, dez constitui, sob todos os aspectos, um fator de escala trivial e idiota. E se o meu lilliput fosse um dos átomos de hidrogênio que integram uma das células do meu corpo? Ele me sentiria como um estranhíssimo Gúliver, dez bilhões de vezes maior que ele. Coloquemos agora a estranheza do nosso lado. Quantas vezes 0 raio da Terra é aproximadamente maior que cada um de nós? Aproximadamente dez milhões de vezes. E o raio do sistema solar? Cerca de dez trilhões de vezes. Acontece que o sistema solar faz parte de uma galáxia, a Via Láctea, em relação à qual somos aproximadamente um quatrilhão de vezes menores. Mas o Universo observável é cerca de um milhão de vezes maior que galáxias de tamanho ordinário como a nossa. Já pensou o que seja sentir-se aproximadamente um sextilhão de vezes menor que o Universo? 0 calafrio que um dos hidrogênios-lilliput sente a nosso respeito é proporcionalmente um quatrilhão de vezes menos intenso em relação ao que deveríamos sentir comparando-nos com a grandeza do universo!

E como devemos nos colocar em relação à escala do tempo? A expectativa de vida do brasileiro, se não me engano, é de 65 anos. A Organização Mundial de Saúde coloca 65 anos como sendo a idade que 
marca o início da velhice. Neste sentido, em média, o brasileiro não tem esperança de atingir a terceira idade. E na escala cósmica? Nela, como algumas linhas abaixo vamos perceber, 1 ano e 65 anos não fazem a mínima diferença. Seria isso um consolo? A idade do Universo está entre 10 a 20 bilhões de anos. Embora os animais e as raças humanas atuais datem de 25.000 a. C. ${ }^{1}$, a história, ou mesmo a proto-história de qualquer povo, não pode ir além de 4.000 anos antes da nossa era². Podemos, para efeito de maior compreensão, imaginar que a história do Universo, até o momento em que apareceram as primeiras civilizações na Terra, estaria escrita em dois mil volumes de uma suposta biblioteca, cada um dos volumes contendo mil páginas. Acontece que o Sol terá condições de aquecer o nosso Sistema Solar, mantendo a vida sobre nosso planeta, ainda aproximadamente por 12 bilhões de anos. 0 que seria a história da humanidade, em relação à expectativa de vida do nosso sistema solar? Seria apenas a primeira página já escrita de uma coleção de mil volumes, cada volume contendo mil páginas, todas as outras ( $n-1)$ páginas restantes sendo ainda uma história a ser escrita!

\section{As quatro antinomias cosmológicas de Kant}

Apresentamos, logo abaixo, as quatro famosas antinomias cosmológicas da razão pura, enunciadas por Kant, e por ele próprio denominadas conflitos das idéias transcendentais ${ }^{3}$. Coloquei letras $T$, designando teses, e A, conotando as antíteses correspondentes. Além do mais, indicamos, ao lado do enunciado de cada uma das teses e das antíteses, o que existe em física atual, a confirmá-las ou a infirmá-las.

T1. "O mundo tem um começo no tempo e é também limitado no espaço" - teoria física comprovada: Big Bang.

A1. "O mundo não tem nem começo nem limites no espaço; é infinito tanto no tempo como no espaço" - teoria física não comprovada: universos paralelos.

T2. "Toda substância composta, no mundo, é constituída por partes simples, e não existe nada mais que o simples ou o composto pelo

${ }^{1}$ E. Burns, História da civilização ocidental, Rio de J aneiro: Globo, 1954 (tradução 1956), 7.

2 M. Crouzet, História geral das civilizações, São Paulo: Difusão Européia do Livro, 1965, tomo I, 1.

3 I. KANT, Crítica da razão pura, Lisboa: Fundação Calouste Gulbenkian, 1989, 392. 
simples" - teoria física comprovada: quarks, elétrons e fótons, como constituintes mais simples da matéria (postura reducionista).

A2. "Nenhuma coisa composta, no mundo, é constituída por partes simples, nem no mundo existe nada que seja simples" - teorias físicas comprovadas: caos, fractais e sistemas complexos (postura holística).

T3. "A causalidade segundo as leis da natureza não é a única de onde podem ser derivados os fenômenos do mundo em seu conjunto. Há ainda uma causalidade pela liberdade, que é necessário admitir para os explicar" - teorias físicas comprovadas: indeterminação na Física Quântica e casualidade na Teoria do Caos.

A3. "Não há liberdade, mas tudo no mundo acontece unicamente em virtude das leis da natureza" - teorias físicas não comprovadas: modelo padrão e supercordas.

T4. "Ao mundo pertence qualquer coisa que, seja como sua parte, seja como sua causa, é um ser absolutamente necessário" - teoria física comprovada: colapso do espaço e do tempo, no infinitésimo de espaçotempo que precedeu ao Big Bang.

A4. "Não há em parte alguma um ser absolutamente necessário, nem no mundo nem fora do mundo, que seja sua causa" - teoria física não comprovada: universos paralelos.

\section{Ciência e ética}

Para Kant, as teses são proposições dogmáticas, não passíveis de verificação experimental, e nem por isso inúteis ou supérfluas. Gozam de grande prestígio, porque estão de acordo com o senso comum. Como indemonstráveis, seja pelo vulgo, seja pelo sábio, colocam o vulgo em pé de igualdade com 0 sábio, podendo mesmo dotá-lo de ares de superioridade a seu respeito. Sua função prática é inestimável. As teses servem de fundamento para a religião e para o comportamento ético. Pasmem. Como as teses propostas por Kant não são mais inacessíveis à física, como indicamos por setas, apontando, a partir de cada tese, para teorias físicas comprovadas, fica a tentação de a física voltar de novo a ser metafísica, e com isto arvorar-se, a seu modo, em religião e ética.

Por outro lado, as antíteses são para Kant proposições puramente empíricas e, portanto, apenas seriam passíveis de verificação experimental. Não gozam de prestígio junto ao vulgo por contrariarem ao senso comum. Não carregam em seu bojo nenhum compromisso com a moral e a religião, mas, pelo contrário, parecem roubar a ambas toda força e influência. E aqui acontece 0 inesperado: as teorias físicas, 
indicadas pelas setas colocadas após os enunciados das antíteses, na seção anterior, têm contestações lógicas sérias e faltam-Ihes comprovações experimentais. Que me perdoem os empiristas rígidos de ontem e de hoje. Existe, como vimos, no entanto, uma exceção, quando se trata do simples e do complexo: tanto para a tese como para a antítese existem teorias físicas comprovadas. Neste caso estamos percebendo que a tese e a antítese são harmonizadas como complementares, pelo menos no âmbito da física.

\section{As partes e o todo}

Ao se postular que o todo se explica a partir de suas partes, opta-se por uma corrente filosófica conhecida sob a designação de reducionista, tendência hoje normalmente execrada a torto e a direito, muitas vezes com razão, mas nem sempre. Vejamos uma de suas caricaturas. "Para o não iniciado, essa corrente filosófica poderia ser denominada 'nadasenãosismo'. 0 reducionista procura reduzir a descrição de um sistema complexo a uma simples receita de ingredientes. Um reducionista vê um ser humano como sendo 'nada senão' tantos litros de água e tantos gramas de cálcio, etc. Contudo, os fatos desvendados por um reducionista são de uso muito reduzido quando se necessita entender o funcionamento do sistema. A partir da lista de ingredientes que constituem o corpo humano, seria muito difícil prever a inteligência do ser humano ou suas emoções ${ }^{4 \prime}$.

0 aspecto grotesco das atitudes reducionistas parece esvanecer-se quando lembramos duas conquistas da pós-modernidade, impossíveis de terem sido levadas a efeito à margem do reducionismo como postura científica: o Big Bang, proeza inventiva dos astrofísicos; o DNA, descoberta ultrafecunda de bioquímicos. Com a palavra Steven Weinberg: "Não prestaríamos muita atenção a uma lei autônoma de macroeconomia que não pudesse ser explicada em termos de comportamentos de indivíduos ou uma hipótese de supercondutividade que não pudesse ser explicada em termos das propriedades dos elétrons, fótons e núcleos. A atitude reducionista fornece um filtro útil que evita que cientistas de todos os campos percam seu tempo com idéias inúteis. Neste sentido somos todos reducionistas hoje" ${ }^{5}$.

Ao reducionismo costuma-se contrapor o holismo, que é, em primeira aproximação, a busca de explicações das partes a partir do todo. 0

${ }^{4}$ B. KAYE, Chaos and Complexity, Weinheim: VCH, 1993, 8.

5 S. Weinberg, Sonhos de uma teoria final, Rio de J aneiro: Rocco, 1996, 58. 
termo holismo, entretanto, pode causar muito embaraço, devido a apropriações indébitas do termo, o que está muito em voga, bastando lembrar a medicina alternativa sem base científica, bem como toda sorte de misticismos isotéricos, herméticos, inconsistentes e ocultistas. Em segunda e mais rigorosa aproximação, na falta de termo melhor, pode-se resgatar a precisão do termo holismo definido-o como "a tendência, que se supõe seja própria do universo, a sintetizar unidades em totalidades organizadas" 6 . No livro de divulgação científica, Caos, James Gleik, jornalista e não especialista na área, conseguiu, com rara felicidade, captar com espírito arguto e difundir, sem deformar, as idéias principais e os resultados mais importante da Ciência do Caos. Ressalto alguns de seus enfoques. Os cientistas da nova ciência, ou seja, do caos, "sentem que estão virando as costas à tendência científica voltada ao reducionismo, a análise de sistemas em termos de suas partes constitutivas: quarks, cromossomas ou neurons" 7 . Cientistas holistas "em vez de quebrarem estruturas, examinando suas partes a seu tempo e em separado, movem-se pela lógica da auto-similaridade e encaram como um todo os mais elevados níveis de complexidade" ${ }^{\text {. }}$.

\section{5. $O$ ser e o não ser do espaço e do tempo}

"Ser ou não ser, eis a questão", frase do Hamlet, de Shakespeare, que transcende à sua criação literária, sendo repetida a torto e a direito, quando alguém assume ares de filósofo. Na peça imortal, tantas vezes mostrada no teatro, no cinema e na televisão, o dialogo de Hamlet é com uma caveira, situada no espaço, é claro, mas simples relíquia de um tempo que já passou. 0 espaço sempre nos pertence, estamos nele e ao mesmo tempo o carregamos. Afirmação do senso comum. 0 tempo não pertence a ninguém, está sempre em fuga. Assim fala a sabedoria popular.

Desde que se inventou a filosofia, na Grécia Antiga, por volta do século VII antes de Cristo, reflexões sobre espaço e tempo permeiam toda a história da filosofia, de maneira sistemática ou não. Vejamos alguns exemplos.

Para Zenão de Eléia (fim do século VI a. C. e início do século V), a divisiblidade do espaço é contraditória: "Aquiles, o de pés ligeiros,

\footnotetext{
${ }^{6}$ A. B. H. Ferreira, Novo Dicionário da Língua Portuguesa, Rio de J aneiro: Nova Fronteira, 1982, 730.

7 J. Gleik, Chaos, New York: Penguin Books, 1988, 5.

8 Ibidem, 115.
} 
nunca alcançará uma tartaruga, pois, para atingi-la deverá percorrer primeiro a metade do espaço que o separa dela, depois a metade da metade, e assim indefinidamente. Ora, existindo uma infinidade de metades das metades, como, em um tempo finito, Aquiles poderá vencer uma distância que é uma soma de infinitas parcelas?"

Para Santo Agostinho (354-430), "Os tempos são três: o presente do passado, o presente do presente e o presente do futuro. $E$, de qualquer forma, é no nosso espírito que se encontram esses três tempos, que não são vistos em outra parte: o presente do passado, vale dizer, a memória; o presente do presente, isto é, a intuição; o presente do futuro, ou seja, a espera" ${ }^{\prime}$.

Para Kant (1724 - 1804), “ ... o espaço é a forma (o modo de funcionamento) do sentido externo (sensibilidade), ou seja, a condição à qual deve satisfazer a representação sensível de objetos externos; já o tempo é a forma (o modo de funcionamento) do sentido interno (e, portanto, a forma de todo dado sensível interno enquanto por nós conhecido). Assim, o espaço abarca todas as coisas que podem aparecer exteriormente e 0 tempo abarca todas as coisas que podem aparecer interiormente" ${ }^{10}$.

Para Sartre (1905-1980), " É impossível captar o presente em forma de instante, pois 0 instante seria 0 momento em que o presente é. $M$ as 0 presente não é; faz-se presente em forma de fuga [ ... ]. É fuga fora do ser co-presente e do ser que era, rumo ao ser que será. Enquanto presente, não é o que é (passado) e é o que não é (futuro)"11.

\section{O início do início}

O Big Bang, modelo da origem do universo, aceito praticamente por unanimidade pelos astrofísicos de carreira a partir dos últimos trinta anos, apoia-se em teorias incontestadas (da relatividade e quântica) e evidências experimentais (falaremos delas mais abaixo). Segundo o Big Bang, o Universo começou há dez ou vinte bilhões de anos, quando era apenas uma bola de fogo ínfima, com apenas dez bilionésimos do metro de raio, ao ter uma idade não superior a um segundo dividido por um seguido de trinta e seis zeros, quando sua temperatura era de um seguido de vinte e sete zeros graus centígrados. De lá para cá, sob o ponto de vista cosmológico, o Universo continua se expandindo e esfriando.

9 Santo Agostinho, Confissões, Petrópolis: Vozes, 1987, 284.

10 G. Reale, D. Antiseri, História da Filosofia, São Paulo: Paulus, 1990, vol. II, 880.

11 J. P. Sartre, O Ser e o Nada, Petrópolis: Vozes, 1997, 177. 
Quais as evidências experimentais a favor do Big Bang? Elas dizem respeito a três importantes predições que foram confirmadas. Primeira predição: o Universo, ao se expandir, acarreta um distanciamento das galáxias, umas em relação às outras, com velocidades proporcionais às distâncias entre elas. Comprovação experimental: desvio para o vermeIho no espectro de luz proveniente de galáxias distantes. Segunda predição: deve haver uma radiação de fundo em todo o Universo, uma espécie de banho térmico remanescente das imensas temperaturas iniciais. Comprovação experimental: existe realmente radiação micro-onda de fundo, recebida uniformemente a partir de todas as direções do espaço, correspondendo a uma temperatura de cerca de duzentos e setenta graus centígrados negativos. A terceira predição é igualmente bem sucedida. Diz respeito à síntese de núcleos atômicos leves, a partir de prótons e neutrons, durante os primeiros minutos que se seguiram ao Big Bang, o que envolveu temperaturas e, portanto, energias, perfeitamente reprodutíveis em muitos dos laboratórios contemporâneos de física das partículas.

\section{0 não-espaço e o não-tempo}

Stephen Hawking ${ }^{12}$ chama a atenção para três espécies de modelos cosmológicos generalizados de Friedmann. Em um deles as galáxias estão se afastando umas das outras vagarosamente o suficiente, de tal sorte que eventualmente a atração gravitacional entre elas interromperá a expansão e elas recomeçarão o movimento de reaproximação. 0 universo expande até um tamanho máximo e então recolapsa. No segundo modelo, as galáxias estão se afastando umas das outras tão rapidamente que a gravidade em momento algum pode freá-las, e 0 universo expande indefinidamente. Finalmente, existe um terceiro modelo, no qual as galáxias estão se afastando umas das outras exatamente a uma taxa crítica para se evitar o recolapso.

0 tempo tem limite ou fronteira em todos os três modelos de Friedmann. A melhor maneira de se visualizar o Big Bang é imaginá-lo como um filme que fosse rodado para trás no tempo. Uma dada região esférica do universo então se contrai, cada vez mais rapidamente, até que seu raio se anula. Neste momento, toda matéria e toda energia que estava contida no volume esférico de espaço estará comprimida em um ponto único ou singular. Teríamos retornado ao primeiro momento do universo primevo.

12 S. Hawking, in Paul Davies (ed.), New Physics, Cambridge: Cambridge University Press, 1993, 61. 
Tomando-se as singularidades a sério, nos modelos idealizados, conclusões importantes se impõem. Devido à compressão infinita de matéria e energia, a curvatura do espaço-tempo, da teoria da relatividade generalizada, torna-se infinita, e os conceitos de espaço e tempo cessam de ter qualquer sentido.

À medida que o recuo no tempo implica em aumento de temperatura, implica também que as diferentes forças atuantes no universo vão perdendo suas identidades, até se fundirem em uma única, à temperatura de $10^{33} \mathrm{~K}$. Ainda mais, todas as partículas subatômicas perdem também suas identidades. A evidência do colapso para a simplicidade provém de muitos anos de estudo na área de física de alta energia (alta energia sendo o equivalente de alta temperatura no presente contexto).

A que corresponde especulativamente o não-espaço? Por uma ginástica mental, extraiamos toda matéria, toda energia do universo, inclusive nós próprios. 0 que restará? 0 nada de matéria. 0 nada de energia. Restará o não-espaço, e, portanto, o nada. 0 que será especulativamente o não-tempo? A negação de toda sucessão, de todo movimento, de todo antes e de todo depois. 0 que restará então? 0 permanecer puro, sem sucessão, um espelho da eternidade.

Existem astrofísicos que se esforçam em propor teorias alternativas ao Big Bang. A de mais prestígio é a dos Universos Paralelos. Parece existir um pano de fundo comum em todas as teorias alternativas, a saber, uma certa má vontade pré-concebida contra as evidências científicas a favor do Big Bang. É como se o fato de admiti-las empurrasse lógica e infalivelmente a mente humana para postular a existência de um Deus criador, o que obviamente não agrada minimamente aos materialistas.

\section{Universos Paralelos}

A teoria dos universos paralelos ou dos universos múltiplos ${ }^{13}$, aceita por um grande número de físicos eminentes, constitui uma das vertentes das interpretações da mecânica quântica. Correndo o risco de uma certa simplificação, seu princípio básico é o de que tudo que pode acontecer, no fundo acontece. Sabe-se da física quântica que existem apenas duas possibilidades de alinhamento do spin eletrônico ${ }^{14}$ a um campo magnético externo: ou ele se acomoda paralelamente (spin para

${ }^{13}$ P. Davies, A mente de Deus, Rio de J aneiro: Ediouro, 1994, principalmente os capítulos 7 e 8 .

${ }^{14} \mathrm{Em}$ termos grosseiros, spin eletrônico é o eixo de rodopio do elétron, no campo magnético, como se ele fosse um peão 
cima) ou antiparalelamente (spin para baixo). Admitida a probabilidade idêntica para um e outro caso, uma visão tosca da teoria dirá que, ao se fazer qualquer medida física, o universo se divide em dois exemplares: um com spin para cima e outro com spin para baixo. Estendida a idéia a todas as partículas quânticas do universo, e não apenas aos elétrons, vê-se que, como resultado de interações físicas, surgem infinitos universos paralelos. Acontece que estamos inseridos apenas em um deles, e todos os outros nos são inacessíveis.

As objeções à teoria dos universos paralelos ou múltiplos são inúmeras e muito sérias. Uma das principais é a multiplicação ao infinito de não observáveis, o que comporta no mínimo dois inconvenientes sérios: inconsistência na fundamentação lógica, ferindo-se o princípio de economia do pensamento (multiplicam-se gratuitamente os universos reais ao infinito); ausência, no fundo, de caráter científico sério (postulandose a inacessibilidade à experimentação física, faltam-lhe as marcas essenciais da falseabilidade e da verificabilidade ${ }^{15}$ ).

Se existe uma imagem de um Deus própria da atualidade, ela o seria de um Deus criador e supremo projetista. Dessa imagem não é muito simples se alijar, conquanto a teoria dos universos paralelos ou múltiplos mostra-se frágil e sem objetividade científica, como foi mostrado logo acima. Tal fato acaba por comprometer a validade da antítese enunciada por Kant, para a primeira de suas antinomias cosmológicas, a de que o mundo não teria nem começo nem limites no espaço e seria infinito tanto no tempo como no espaço.

\section{Mergulho no simples}

Para Demócrito (meados do século $V$ a. C.), a verdade estaria no mais profundo das coisas, e, afirmava ele, "o mais profundo das coisas são os átomos e o vazio". Contaram-me, há muitos anos atrás, que, no jardim principal da Universidade de Harvard, nos Estados Unidos, estaria erigido um busto de Demócrito, e não o de Sócrates, Platão ou Aristóteles, tal a importância que se quis dar àquele que pode ser considerado como sendo o pai da teoria atômica da matéria. Confesso que, quando estive lá, não me ocorreu conferir!

Átomo é palavra grega que significa indivisível. A proposição de Demócrito foi meramente especulativa e acabou caindo no ostracismo por impossibilidade de verificação experimental. Aristóteles estava afi-

15 K. R. Popper, El desarrollo del conocimiento científico, Buenos Aires: Paidos,1965, capítulos 3, 10 e 11 . 
nado com o senso comum, quando propôs terra, água, ar e fogo, como os quatro elementos fundamentais. Tudo tangível. Tudo palpável. Mesmo que no caso do fogo nos queimemos... Os quatro elementos de Aristóteles tiveram vida longa: do século IV antes de Cristo, até fins do século XIX, com 0 advento da química moderna.

Hoje sabemos que os átomos, herdados da postulação de Demócrito, são eles próprios divisíveis, não constituindo a última e mais elementar porção de matéria. Quais são os ingredientes para se examinar os elementos constitutivos de qualquer coisa? Pelo menos três: fonte de iluminação ou radiação; objeto respondendo a essa iluminação ou radiação; detecção da resposta do objeto iluminado ou submetido à radiação. Um exemplo de nossa vida quotidiana: sol, como fonte de iluminação; atmosfera chuvosa, como objeto iluminado; olho humano, detectando a decomposição da luz solar nas cores do arco íris.

0 olho humano responde a radiações eletromagnéticas, cujos comprimentos de onda se situam em uma faixa muito estreita. A chamada "Iuz visível", com o auxílio de microscópios óticos, não permite distinguir grandezas inferiores a um milésimo de milímetro. Para ir além é necessário armar-se de radiações mais poderosas.

Feixes de elétrons acelerados por voltagens muito grandes, em substituição à "luz visível", permitem, com os chamados microscópios eletrônicos, distinguir estruturas na escala de moléculas, mas raramente na escala de átomos individuais.

Para se ir além da escala molecular é necessário utilizar aceleradores de partículas, com vários quilômetros de comprimento, capazes de produzir feixes de elétrons, poderosos o suficiente, para revelar a estrutura interna dos núcleos atômicos. Desvenda-se, então: os núcleos atômicos são constituídos de prótons, portadores de cargas elétricas +1 , e de nêutrons, destituídos de cargas elétricas. Mas isto não é o fim. Nova invasão de privacidade! Prótons e nêutrons são constituídos de quarks. Estes sim, em companhia de elétrons, com cargas elétricas -1, e fótons, sem cargas elétricas e destituídos de massa de repouso, parecem constituir o que há de mais elementar na matéria.

\section{Seriam os quarks brincalhões?}

No que depende dos físicos de partícula, sim. É fácil de se compreender. Desde a década de 60 cultiva-se menos o gosto pelo latim e pelo grego. Por outro lado, nomes gregos têm tido às vezes 0 efeito de armadilhas: átomo significa indivisível, mas se mostrou divisível; próton, como partí- 
cula primeira, seria simples, e, no entanto, se revelou composta. Além do mais é muito pós-moderno fazer brincadeiras, simulando-se que estamos sempre nos divertindo, mesmo falando de coisas sérias. É como se esta atitude eliminasse todo estresse.

Numa cervejaria: "three quarters for Mr. Mark"! Na física: "three quarks", com dois sabores, na seqüência uud, e tem-se o próton; "three quarks", com dois sabores, na seqüência, udd, e tem-se o nêutron. É claro que o nome sabor é uma brincadeira. E quais são os sabores elementares? Up, com carga elétrica $+2 / 3$; down, com carga $-1 / 3$; charme, com carga +2 / 3; estranho, com carga $-1 / 3$; top, com carga $+2 / 3$; e botton, com carga $1 / 3$. A seqüência udd significa: 1 quark up $(+2 / 3)+1$ quark up $(+2 / 3)$ +1 quark down $(-1 / 3)=1$ próton $(+1)$. E como se fabrica o nêutron, que é destituído de carga elétrica? 1 quark up $(+2 / 3)+1$ quark down $(-1 / 3)$ +1 quark down $(-1 / 3)=1$ nêutron $(0)$.

Não é tudo. Continuemos a ler o glossário dos quarks, que é um glossário de brincadeiras. Uma outra propriedade, que é a das cores, tem implicações mais sérias ainda que o jogo dos sabores. Essa brincadeira é tão séria, que com ela se criou um novo e importante campo na física contemporânea, a Cromodinâmica Quântica. Nela o glúon (falaremos dele logo a seguir!), desempenha papel análogo àquele desempenhado pelo fóton na Eletrodinâmica Quântica, da mesma maneira que o fóton desempenha na Eletrodinâmica Quântica, função parecida à do elétron, no Eletromagnetismo.

O glúon (por que não chamá-lo, em português, de grúdon, inspirandonos em grude?) é sensível ao que seriam as três cores elementares, verde, vermelho e azul, criando campos fortes de curto alcance que dão estabilidade às partículas elementares compostas, como 0 próton e 0 nêutron. Por sua vez prótons e nêutrons, embora compostos de quarks das três cores elementares (verde + vermelho + azul $=$ branco), não são sensíveis a cores, o branco sendo interpretado como ausência de cor.

\section{Do dogma às evidências}

Como salientamos, em outra seção do presente trabalho, para Kant as teses de suas famosas quatro antinomias cosmológicas seriam meras afirmações dogmáticas e do senso comum, e as antíteses, afirmações do senso científico. Como se colocam as coisas, hoje, em relação à tese de sua segunda antinomia: "Toda substância composta, no mundo, é constituída por partes simples e não existe nada mais que o simples ou 0 composto pelo simples"? Longe de ser um dogma, e como tal inacessível à razão e à experimentação, trata-se hoje de uma evidência cien- 
tífica. Constitui domínio da física de partículas, suficientemente comprovado e firme, seja sob o ponto de vista teórico (teoria da relatividade e física quântica), seja sob o ponto de vista experimental (aceleradores de partículas). Partículas fundamentais simples (entre elas: quarks, elétrons, fótons) colocam-se como ponto de partida das partículas fundamentais compostas (entre elas: próton, nêutron, méson) e de sistemas complexos, em todas as suas gradações (entre eles: núcleo atômico, átomo, molécula, estrutura inorgânica, estrutura orgânica, célula, tecido, cérebro). A antítese não estaria em contradição com a tese, significando apenas o produto de uma atitude complementar (holística em vez de reducionista). É o que tentaremos esclarecer logo abaixo.

\section{Fractais, caos e complexidade}

Fractais ${ }^{16}$ são sistemas complexos desprovidos de escala característica de comprimento. Um exemplo bem conhecido é a forma de um litoral. Quando vemos duas fotos de um mesmo litoral, com $1 \mathrm{~cm}$ correspondendo a $100 \mathrm{~m}$ ou a $10 \mathrm{~km}$, permanecemos incapazes de dizer em qual escala cada uma das fotos foi feita. Elas são semelhantes. Isto significa que o litoral é invariante quanto à sua escala, ou, equivalentemente, não tem escala característica de comprimento.

Existem fractais em toda a natureza, seja ela de escala astronômica, humana ou microscópica. Para citar apenas alguns exemplos: os amontoados de galáxias; a paisagem vulcânica da lua; a distribuição das fissuras provocadas por terremotos terrestres; a estrutura de litorais, rios, montanhas e nuvens; a estrutura dos galhos e das raízes de certas plantas; a couve-flor, o brócolis e a samambaia; a estrutura dos vasos sangüíneos de nossos pulmões; a estrutura dos neurônios da nossa retina; a estrutura de amontoados de moléculas de DNA; a estrutura das trajetórias em movimentos ao acaso. Sob o ponto de vista matemático, a dimensionalidade de fractais não é inteira mas fracionária. Estruturas fractais acontecem freqüentemente em sistemas caóticos.

Por volta dos anos 70, um número muito grande de cientistas experimentou profundo choque cultural ao deparar com montanhas de números fabricados por computadores, pondo a descoberto muitos sistemas físicos que, embora essencialmente determinísticos, eram tão sensíveis às condições iniciais que qualquer esperança de predizer seu comportamento futuro, embora constituísse uma possibilidade teórica, permaneceria para sempre um sonho impraticável. Quando cientistas

${ }^{16}$ I. C. Moreira, Fractais, in H. M. Nussenveig (org.) Complexidade e Caos, Rio de J aneiro: Editora UFRJ/COPEA, 1999, 51. 
contemplaram as predições surpresa de seus computadores, eles batizaram com o nome de caos determinístico o novo assunto relacionado com o comportamento complexo de sistemas sensíveis às condições iniciais.

Por outro lado, denominam-se complexos sistemas não suficientemente desorganizados para merecerem o adjetivo 'caótico'. Representam, no entanto, sistemas que são imprevisíveis em casos específicos, mas que geram padrões de comportamento que, embora surpreendentes, ocorrem com regularidade espantosa. A auto-organização espontânea em sistemas físicos e químicos simples é tão surpreendente como fácil de se explicar, ordem que nasce do caos, gerando sistemas complexos.

\section{Reflexões em cenário bucólico}

Um fim de semana longe da cidade grande, em contato direto com a natureza imperturbável do campo, em solidão, eis o cenário ideal para se pensar e se refletir pachorrentamente, em bucólica descontração. Passa um bando de maritacas em revoada desordenada pelo céu, colorindo com alaridos alegres, verde papagaio, azul e amarelo bandeira nacional, e, como fundo, o contraponto do céu tingido de anil. Algazarra de revoada desordenada... como maritacam as maritacas! E a natureza continua imperturbável. As maritacas se aquietam, distribuindo-se em árvores da redondeza. Segue-se então uma outra revoada. Esta sem alaridos. Ouvem-se apenas rufares de asas longínquas. São mergulhões. Manchas pretas aladas, formando belo e frouxo " $V$ ". A que se deve a formação em "V"? Por que me veio esta pergunta, em um belo dia de sábado, feito para curtir, feito para esquecer ruídos metálicos de motores, roucos de poluição, infestadores das cidades grandes?

A formação na revoada dos mergulhões, em dinâmico e frouxo " $\mathrm{V}$ ", teria alguma explicação simples, tipo reducionista? Seria o todo sendo explicado a partir da justaposição de partes? Parece que não. Não se trata de um "V" tipográfico, sucessão de minúsculas manchas negras, indiscerníveis individualmente a olho nu, dando a ilusão do contínuo, em manchete de jornal: "Voou tudo pelos ares. Violenta explosão destruiu depósito de munições".

Não, não é nada disto. A explicação da revoada dos mergulhões, formando belo e frouxo " $V$ ", só pode ser entendida ou explicada em enfoque holístico: a partir do todo (entendimento do porquê e do como nasce o comportamento coletivo) explicar o comportamento das partes. E quando se fala em holismo, tem-se de encarar diretamente a complexidade do todo, de frente e com ousadia. Vou tentar fazê-lo agora, por 
mais prazeroso que possa ser, continuar contemplando o belo e frouxo "V" da revoada dos mergulhões.

\section{Emergências da complexidade}

A exigência da postura holística, em contraposição à reducionista, fica clara, toda vez que se trata de explicar propriedades e características emergentes. Um exemplo simples: o gás hidrogênio é combustível, pega fogo e, dependendo do contexto, explode; o gás oxigênio é comburente, não pega fogo, mas alimenta a combustão. Da combinação do hidrogênio com o oxigênio, de acordo com a tão conhecida reação química $(4 \mathrm{H}$ $+\mathrm{O}_{2}->2 \mathrm{H}_{2} \mathrm{O}$ ), emerge a água, que não é nem combustível e nem comburente. Trata-se de um sistema mais complexo que os gases hidrogênio e oxigênio tomados separadamente. Com esta afirmação, ressaltase apenas o aspecto estático e estrutural da complexidade da molécula de água, comparada com a de seus átomos constituintes.

0 que se entende por complexidade ${ }^{17}$, tomada sob 0 ponto de vista dinâmico? Ela se coloca a meio caminho entre a ordem e o caos. $\mathrm{Na}$ ordem, a evolução de qualquer sistema é totalmente previsível, manifestando a regularidade de um relógio. No caos, o sistema muda o tempo todo, mas quanto mais muda, mais permanece sendo ele mesmo. A irregularidade é completa. Pense nas posições aleatórias das moléculas que compõem 0 ar da sala em que você está. Na complexidade tem-se um meio caminho entre a ordem e o caos: quanto mais muda, mais diferente fica. Pensemos na evolução das espécies, gerando organismos vivos, ou seres complexos adaptativos.

Sistemas que evoluem espontaneamente do caos para a complexidade 0 fazem a partir de criticalidades auto-organizadas, ou seja, não sintonizáveis a partir de parâmetros externos. Eis um exemplo simples: dispositivo que solta vagarosamente grãos de arroz, um a um, sobre uma plataforma horizontal - não existem parâmetros externos capazes de sintonizarem para que lado os grãos de arroz vão tombar, quando ocorrerão avalanches de grãos que despencam do monte cônico que se auto organiza, nem sua intensidade, ou seja, a quantidade de grãos que despencam em cada avalanche. Existem, no entanto, algumas características comuns a todo comportamento estatístico de criticalidades autoorganizadas. Citemos duas delas: seguem leis de potência e têm dupla escala de tempo.

17 H. M. Nussenveig, Introdução à complexidade, in op. cit., 1. 


\section{Leis de potência, o imenso e o ínfimo}

Qual a probabilidade de ocorrência: de avalanches em montanhas de grãos de arroz empilhados, vagarosamente e um a um; de terremotos em regiões sujeitas a abalos sísmicos freqüentes; de episódios de extinção de espécies na sucessão de períodos geológicos; de erupções vulcânicas em regiões a elas sujeitas?

Em tudo que mencionamos acima, as probabilidades de ocorrência retratam equilíbrio instável intrínseco entre ordem- desordem, instabilidade essa característica de sistemas complexos. As previsibilidades em sistemas complexos implicam em leis de potência, cuja natureza é estatística, e, portanto, estabelecidas em um enquadramento epistemológico totalmente diferente daquele característico das leis de potência do tipo relógio suíço. A lei da gravitação universal de Newton é um exemplo típico de lei de potência à moda suíça: "Matéria atrai matéria na razão direta de suas massas e na razão inversa do quadrado da distância que as separa". Na razão inversa ... Vale o mesmo que dizer: ... e na razão da distância, que as separa, elevada à potência menos dois.

Avalanches, terremotos, extinções de espécies biológicas, erupções vulcânicas, seguem alguma lei, qual seria? Tudo leva a crer que existem famílias de universalidades, ligadas a valores do expoente $n$, em leis de potência, de natureza estatística, regendo tudo isso, também conhecidas como leis $1 / f^{n}$, sendo: $f$ a freqüência ou probabilidade de ocorrência do evento; $n$ um expoente inteiro ou fracionário ${ }^{18}$. Traduzindo em uma outra linguagem bem genérica: quanto maiores as avalanches e os terremotos, menores as suas probabilidades de ocorrência. 0 mesmo vale para as erupções vulcânicas. E o ponto talvez mais interessante: encarando-se os episódios de extinção de espécies como avalanches, extinções em larga escala são muito mais raras.

E o que diz respeito à dupla escala de tempo, regendo a complexidade? A formação de pilhas de arroz, lentamente, grão a grão, constitui um bom modelo teórico, embora as simulações em computador (experimentações in silico), neste caso, não sejam feitas a três dimensões, e, na prática (experimentações in situ), pilhas de grãos reais em formação não apresentem necessariamente criticalidades auto-organizadas. Tudo depende, entre outras coisas, da forma dos grãos e de quão rapidamente a energia deles é dissipada durante o empilhamento. O correndo, no entanto, a criticalidade auto organizada, existe, na complexidade do seu dinamismo, uma dupla escala de tempo: uma muito grande ou imensa

\footnotetext{
${ }^{18}$ No caso de expoente fracionário, tem-se o que se denomina dimensionalidade fractal, a fractabilidade de sistemas físicos já tendo sido abordada no presente trabalho.
} 
(tempo até que se forme um monte cônico, com inclinação de rampa em ângulo crítico, ou seja, dotado de robustez auto regenerável, embora a pilha continue sujeita a avalanches) e outra ínfima (tempo de duração de cada avalanche).

É fácil de se ver que a dupla escala de tempo está também presente em avalanches em montanhas cobertas de neve, terremotos, erupções vulcânicas, extinções de espécies biológicas. Por outro lado, encarada mais de perto, como a aventura da complexidade nos toca, a nós humanos, frágeis seres mortais? De uma maneira desconcertante. De um lado, como seres complexos adaptativos, temos a robustez estatística de criticalidades auto-organizadas. Cabe aqui a metáfora da pilha de arroz. Ela resiste a despencar espontaneamente, embora esteja sujeita a avalanches: doenças, cansaços, prostrações. Por outro lado, eis a sina inexorável: toda complexidade orgânica, a partir de um determinado grau de organização, está programada para a morte. Grãos de arroz também envelhecem e dão carunchos! Um dia a pilha de arroz despenca, mesmo que não haja cataclismos externos sacudindo a plataforma de sustentação.

Um dos aspectos mais excitantes do estudo de fractais, caos, sistemas complexos, é que a universalidade dos padrões gerados é independente de seus detalhes. Circuitos elétricos simples e modelos matemáticos nada sofisticados podem ser aplicados diretamente para se compreender o que há de caótico no comportamento da meteorologia, da ecologia, do cérebro, do sistema imunológico, das oscilações de preços.

Quem sabe, depois de tantos mergulhos bem sucedidos no infinitamente pequeno das partículas elementares, e das mais variadas incursões coroadas de êxito no infinitamente grande do nosso universo em expansão, não estaríamos nos preparando adequadamente para entender 0 infinitamente complexo, o cérebro humano?

\section{Conclusão}

Do acima exposto, penso ter ficado claro que o fato de a Teoria do Bing Bang ou da Explosão Primeira, dando origem ao Universo, e, portanto ao espaço-tempo, estar firmemente consolidada, arranca o caráter dogmático da tese da primeira antinomia de Kant, transformando-a em evidência científica: espaço e tempo são finitos; existe um começo tanto para o espaço como para o tempo. Cabe aqui uma reflexão: a matemática é a linguagem da física, mas como linguagem ela é mais ampla que a física. Existem idealidades matemáticas que não têm contrapartidas como realidades físicas, uma delas é a infinitude do espaço-tempo. Isto não deve causar espanto. A linguagem humana é também muito mais ampla 
que qualquer realidade, seja ela de natureza humana ou física. Permite ela, entre outras muitas coisas, forjar sonhos, devaneios, fantasias e quimeras.

0 passo seguinte, por mim seguido, foi mostrar que a física de partículas, de um lado, e fractais-caos-complexidade do outro, corroboram como enfoques científicos complementares, tanto a tese (a da simplicidade) como a antítese (a da complexidade), no que diz respeito à segunda antinomia cosmológica de Kant.

Por último, mas não o último aspecto em importância, convém ressaltar que 0 que apresentei é apenas um ensaio crítico. Longe de mim acreditar ser ele detentor da abrangência e profundidade que os tratados, sobre qualquer assunto que seja, devem ter.

Endereço do Autor:

Rua Ceará 1191, Ap. 801

30150-311 Belo Horizonte - MG

ionsuper@dedalus.Icc.ufmg.br 